IZA DP No. 7405

Working Conditions and Job Satisfaction of China's New Generation of Migrant Workers:

Evidence from an Inland City

Huashu Wang

Lei Pan

Nico Heerink

May 2013 


\title{
Working Conditions and Job Satisfaction of China's New Generation of Migrant Workers: Evidence from an Inland City
}

\author{
Huashu Wang \\ Guizhou University \\ Lei Pan \\ Wageningen University \\ Nico Heerink \\ Wageningen University, Zhejiang University, \\ Nanjing Agricultural University and IZA
}

Discussion Paper No. 7405

May 2013

IZA

P.O. Box 7240

53072 Bonn

Germany

Phone: +49-228-3894-0

Fax: +49-228-3894-180

E-mail: iza@iza.org

\begin{abstract}
Any opinions expressed here are those of the author(s) and not those of IZA. Research published in this series may include views on policy, but the institute itself takes no institutional policy positions. The IZA research network is committed to the IZA Guiding Principles of Research Integrity.

The Institute for the Study of Labor (IZA) in Bonn is a local and virtual international research center and a place of communication between science, politics and business. IZA is an independent nonprofit organization supported by Deutsche Post Foundation. The center is associated with the University of Bonn and offers a stimulating research environment through its international network, workshops and conferences, data service, project support, research visits and doctoral program. IZA engages in (i) original and internationally competitive research in all fields of labor economics, (ii) development of policy concepts, and (iii) dissemination of research results and concepts to the interested public.
\end{abstract}

IZA Discussion Papers often represent preliminary work and are circulated to encourage discussion. Citation of such a paper should account for its provisional character. A revised version may be available directly from the author. 


\section{ABSTRACT \\ Working Conditions and Job Satisfaction of China's New Generation of Migrant Workers: Evidence from an Inland City}

China is experiencing notable changes in rural-urban migration. Young, more educated migrants with different attitudes towards living and working form an increasing share of the migrant labour force. At the same time, the destinations of migrants are changing as a result of government policies and the global financial crisis. More migrants than before find jobs in medium and small size cities, often located in western and central China. Understanding the characteristics and attitudes of the changing migrant labour force is becoming a major challenge in sustainably managing migration flows and urbanization. Little hard evidence is available on the working conditions and job attitudes of migrant workers, particularly for inland China. The purpose of this paper is to provide insights into the characteristics, working conditions and job attitudes of the new generation of migrants, defined as those born in the 1980 s and 1990s, as compared to the traditional generation in a typical medium-size city in western China. Data collected through a household survey conducted among 1,048 migrants in Guiyang City, capital of Guizhou Province, are used for this purpose. We find significant differences in occupational characteristics and working conditions between the two generations. Contrary to popular beliefs, we find that the level of job satisfaction is higher among the new generation of migrants. Using an ordered logit model to examine factors contributing to job satisfaction, we find that age and gender do not have a significant impact for young migrants, while working conditions play a major role. Among these, it is not so much the income level that matters for young migrants, but other working conditions. Using a Blinder-Oaxaca decomposition, we derive that it is mainly the difference in working conditions and other endowments that explains the higher job satisfaction of young migrants, not the differences between generations in the valuations of these endowments.

JEL Classification: J61, O15

Keywords: migrant workers, new generation, working conditions, job satisfaction, China

Corresponding author:

Nico Heerink

Development Economics Group

Wageningen University

Hollandseweg 1

6706KN Wageningen

Netherlands

E-mail: Nico.Heerink@wur.nl 


\section{Introduction}

China has experienced massive migration of people from rural to urban areas since the start of the economic reforms and opening up at the end of 1970s. According to official statistics, the size of the migrant population equalled 253 million in 2011 (i.e. 18.8 percent of the total population), with 159 million migrants working outside and 94 million migrants working inside their own provinces for more than six months per year (NBSC, 2012). This immense flood of internal migrants has played and continues to play a key role in China's economic "miracle".

Two recent phenomena are vitally changing the characteristics of China's rural-urban migration. In the first place, a new generation of migrants born in the 1980s and 1990s is emerging that is more urbanized, more aware of its own rights, less obedient, and prefers to settle down in cities instead of returning to the rural areas. The term "new generation of migrant workers" was officially introduced by the Chinese government in its so-called No.1 Document of 2010, the major policy document released at the beginning of each year to address government priorities. To deal with the challenges posed by this new generation, the document points out that the government will take new measures to integrate more farmers into urban life, like easing restrictions on permanent residence permits, urban housing programmes, and including migrants in the basic medical insurance and pension program in cities (Cao and Lin, 2010).

Secondly, the spatial pattern of migration flows is changing in recent years. The proportion of migrants moving towards the eastern regions is slowly declining, while the concentration of migrants in key regional cities in central and western China is going up (NPFPC, 2012). With government policy priorities shifting towards the development of central and western China, particularly through the "Western Development" or "Go West" policy that started in 1999 (e.g. Yeung and Shen, 2004; Lu and Deng, 2011), more off-farm employment opportunities have become available in inland provinces since the turn of the century. This changing trend in migrant destinations was further strengthened by the global financial crisis of 2008 , which considerably reduced employment in the export-oriented coastal provinces, and by the macroeconomic stimulus package adopted by the Chinese government in response to the global crisis. It stimulated rural migrants from western cities and towns to seek work in their home provinces by providing financial and logistical support, and encouraged provincial governments to provide retraining to improve rural migrants' skill (Cai et al., 2010; Hsu et al., 2010; Huang et al., 2011). The Spring Wind Action Program launched in 2008 by the Ministry of Human Resources and Social Security (MHRSS) further stimulated rural migrants to seek work in their home provinces by providing financial and logistical support, and encouraged provincial governments to provide retraining to improve rural migrants' skill (MHRSS 2008). Another policy contributing to the shift in migrant destinations is the recent change in focus of China's urbanization policy. To avoid that congestion, pollution, security and other typical problems of mega-size (mainly coastal) cities like Beijing, Tianjin, Shanghai, Shenzhen and Guangzhou become unmanageable, the transfer of a significant share of rural-urban migrants into small and medium-sized cities and towns (usually located closer to their hometowns) is considered one of the major projects for the country's urbanization in the near future (e.g. Cao and Lin, 2010). 
An important topic in the available literature on rural-urban migration in China is the economic inefficiency caused by market segmentation between migrants and urban workers (Wang and Luo, 2012). Available studies focus in particular on the role of the hukou (residence permit) system and social networks (Chen et al., 2009), on the segmentation by economic sector and type of ownership (Wang, 2010; Wang and Cui, 2010), and on the effects of segmentation on earnings differentials and income distribution (Meng and Zhang, 2001). Potential differences between different generations of migrants tend to be overlooked in these studies. Other studies emphasize that the new generation of migrants struggles with the segmentation, inequality and discrimination in the urban labour market, and has started to assert themselves in various ways which sometimes aroused much public concern (Pun and Lu, 2010; Wong, 2010). They no longer take the relative low earnings and long working hours, as compared to the urban peers, and the lack of social security for granted.

Insights into the differences in characteristics between the old generation and the new generation of migrants, and especially into their working conditions and job attitudes, can provide an important contribution to policies that strive to maintain a sustainable migration and urbanisation process. At the same time it can also help to reduce economic inefficiencies that result from the natural segmentation into different generations of migrants. To our knowledge a rather limited body of literature is available in this respect. Several studies report that the education level of the new generation rural migrants is higher than that of their predecessors (e.g. ACFTU, 2011; NPFPC, 2012; Liu, 2010; Wang, 2010). Although the better education background allows the new generation of migrants workers to enter into broader and more ambitious careers, the type of occupations in which they work is very similar to that of the old generation in Beijing, Shanghai and other big cities. (NPFPC, 2011; NPFPC, 2012).

The present study aims to add to this literature by carrying out a rigorous empirical analysis of the differences in working conditions and job attitudes between the new and traditional generation of migrants in an inland city. Special attention will be paid to differences in job satisfaction between the two generations, and the factors driving these differences, as job satisfaction is both an important indicator of workers' wellbeing and a major contributing factor to job performance. More specifically, four research questions will be addressed in this study.

First, what are the major socio-economic and occupational characteristics of the new generation of migrant workers in a median size city in inland China, and to what extent do these differ from those of the traditional generation?

Second, what are the differences in working conditions and job attitudes between the new generation and traditional generation of migrants in that city?

Third, what factors contribute to the observed difference in job satisfaction between the two generations of migrants?

Fourth, to what extent is the observed difference in job satisfaction between the two generations related to differences in endowments or by differences in subjective valuations of factors that contribute to job satisfaction?

To answer the first and second research question, the statistical significance of differences in sample means for the two sub-sets of migrants will be tested through t-tests. An ordered logit regression model will be estimated for the whole sample and for each of the two generations of 
migrants to examine the factors contributing to job satisfaction of the different generations (third research question). The regression results will be used in a Blinder-Oaxaca decomposition to investigate the relative contributions to job satisfaction of endowments and subjective valuations by each generation of the factors that contribute to job satisfaction (fourth research question).

Migrant survey data used in this paper was collected in August 2011 in Guiyang City, the capital of Guizhou Province, southwest China. As a typical medium-size city with an urban population of 3.0 million, Guiyang has absorbed more than 1.1 million rural migrants in 2011, mainly from within the own province, accounting for 47 percent of the total migrant population in Guizhou (PFPC, 2011). Like other key regional cities in western China, it is expected to absorb increasing numbers of migrants in the process of urbanization (Guiyang Municipal Government, 2011). It was also selected in 2010 by the central government as one of the 49 cities where a pilot project aimed at reducing labour market segmentation was introduced; the measures taken focus on innovating services and management systems for migrants and promoting equalization of basic public services between migrants and urban workers (NPFPC, 2010). Out of these 49 pilot cities, 10 are located in western China, in which the local governments are under an enormous strain in managing the rapidly growing inflow of migrants due to existing deficiencies in availability and quality of public services and due to lack of experience and knowledge. The findings obtained from this research are meant to understand the (changes in) the characteristics of migrants in west China, to assist in further improving the governance of ruralurban migration flows in western China by providing important insights into the differences in working conditions and job attitudes between different generations of migrants in a medium-size city in western China where labour market segmentation is being reduced.

The paper is organized as follows. Section 2 reviews the available literature on job satisfaction and on differences between the new and old generation of migrants in China. Section 3 examines the differences between the two generations in socio-economic and occupational characteristics and in job attitudes for migrants interviewed in the survey. Section 4 presents the results of the ordered logit regression model and the Blinder-Oaxaca decomposition of factors contributing to job satisfaction. Finally, in section 5, the main conclusions are summarized and their implications for policy making are discussed.

\section{Literature review}

Job satisfaction is one of the important attitudes influencing working behaviour. Katz defines attitudes as the predisposition of an individual to evaluate a particular object in a favourable or unfavourable manner (Katz, 1960). Job attitudes are the multidimensional psychological responses to one's job. Three major elements can be distinguished: satisfaction, commitment and engagement (Cascio and Boudreau, 2008).

Locke (1976) defines job satisfaction as a pleasurable or positive emotional state resulting from the appraisal of one's job, job achievement or job experiences. The concept of job satisfaction can be used to get more insights into the state of aggregate well-being generated by a job, which cannot be fully represented by income (Bender et al., 2005). Studies on job satisfaction have provided strong 
evidence that people work for purposes other than payment alone. Working is not only for earning money, but also for seeking happiness and self-realization.

Available sociological and economic research on job satisfaction focuses on its determinants and effects. One of the first studies in this field, by Gurin et al. (1960), examines the relationship between occupational status and job satisfaction. It finds that job satisfaction is related to success in climbing the occupational hierarchy. Job satisfaction is highly correlated with demographic characteristics. It has been found that relatively young and relatively old workers, as well as women, have higher job satisfaction (Clark et al., 1998; Bender et al., 2005). On the effects of job satisfaction, Clark et al. (1998) find that workers who report low job satisfaction have higher absenteeism and are more likely to quit their jobs. In some industries, job satisfaction correlates positively with customer satisfaction and with firm's performance (Rogers et al., 1994; Freeman et al., 2008).

Job satisfaction and, more generally, job attitudes and working conditions of migrant workers have not been an issue of academic concern until recent years in China. Li (2008) examines the unfavourable working conditions of many rural migrant workers in the Chinese labour market, in particular the low wages, the problems of wage arrears, the lack of written contracts, the long working hours, the short weekly rest periods, the low social security coverage, the poor housing conditions, and the difficulties they face in accessing public services. $\mathrm{Li}$ and $\mathrm{Li}$ (2007) analyse the economic status and social attitudes of migrant workers in China using data from of a large-scale survey carried out in 2006. Their study finds that the economic and social status of migrants is negatively related to their attitudes to society, and that the determinants of migrant workers' attitudes and behaviour are historic rather than economic. Qian and Zhang (2009) examine the relation between work and family life and its impact on job satisfaction of rural migrants in three cities in coastal Zhejiang Province. They find that migrants' feelings are significantly affected by the quality of the relationship between work and family life. Good relationships have a significant positive effect on the job satisfaction of rural migrants.

There is a growing number of studies on China's new generation of migrants, i.e. migrants who are born in the 1980s and 19990s, The focus of these studies is mainly on the characteristics, aspirations and social integration of the new generation. To our knowledge no studies have examined differences in working conditions, job satisfaction and other job attitudes between the new generation and the old generation. Moreover, the focus of most studies is on coastal provinces, thereby disregarding the major change in migration directions that can be observed in recent years. Wang (2003) studies the characteristics and social identity of the new generation of migrants in China in a survey held among migrants in three cities in coastal Zhejiang Province. He finds that migrants belonging to the new generation are better educated, have little or no farming experiences, and are more aware of their identity and status in the city. Yue et al. (2009) conclude from data collected among migrants in Shenzhen that, while previous generations tended to live transiently in cities for the main purpose of earning money, new-generation migrants intend to accumulate human and social capital in order to settle permanently in a city. Using data from the "Chinese General Social Survey" carried out by the Institute of Sociology, Chinese Academy of Social Sciences, Li and Tian (2011) find that changes in life pressure and enhanced awareness of individual rights have significantly changed the social attitudes and behavioral choices of the new generation. Liu et al. (2012) examine the differences in 
social networks between the two generations in a case study of Guangzhou. Their study finds significant differences, with new-generation migrants more likely to draw on cross-class, non-kin, and non-territorial networks when seeking social support, and to construct colleagues networks and friendship ties that transcend the boundaries of the receiving neighborhoods

This study focuses on differences in working conditions and in job satisfaction and other job attributes between the two generations of migrants. Working conditions and job attitudes are important elements of workers' wellbeing that deserve adequate attention by business leaders, government officials and researchers. Moreover, the degree of job satisfaction is a major contributing factor to job performance. Stimulating higher job satisfaction among migrant workers can therefore play an important in the further raising the productivity of Chinese workers. Given that new generation migrants are better educated, less obedient and more aware of their own rights, we expect that these younger migrants face better working conditions and are more ambitious in their careers. On the other hand, they may have a lower level of job satisfaction because they are less willing to accept the (also in Guiyang) still existing segregation of the labour market.

\section{Characteristics, working conditions and job attitudes of migrants}

The data that we use for our analysis are collected through a migrant survey organized by Guizhou University in Guiyang City in August 2011. The survey was sponsored by the Population and Family Planning Commission (PFPC), People's Government of Guiyang Municipality. We randomly selected 1,048 rural migrant workers from PFPC's list of registered migrants. Local officials and researchers involved in the survey assume that the list includes nearly all migrants in the city, because registration is a basic requirement to be included in the local social welfare system. In that way, migrants are entitled to receive free compulsory education for their children and to participate in medical care insurance and other programs designed for them. Nevertheless, migrants who stay a long period generally are more willing to register themselves than those who stay temporarily or have not yet made a decision to stay. Hence a small sample selection bias is inevitable.

The collected survey data provide information on demographic characteristics, socio-economic background, living conditions, working conditions, social insurance, job attitudes, expectations, and related variables. It is collected for one point in time, August 2011. It can be used for comparing characteristics, attitudes and working conditions of the new and old generation of migrants who were in Guiyang City at that specific moment. In doing so it should be realised that life cycle effects may affect such a comparison. For example, if job satisfaction declines with age, the older generation will have a relatively lower job satisfaction when other conditions are similar for the two generations. Likewise, if older migrants have returned to their home villages after earning sufficient money for getting married and starting their own business, the average income level of the older generation will be lower than it would be otherwise. The survey data that we have at our possession do not allow us to separate life cycle effects from other effects. Yet a simple, straightforward comparison of differences in working conditions and job attitudes between the old and the new generations of migrant workers in 
a rapidly changing society, like Guiyang City, may provide many relevant insights that can be used for developing targeted migration policies that appropriately differentiate between the two generations.

According to statistical data of MHRSS of Guizhou and calculations by Liu and Zhou (2011), the new generation of migrant workers in Guizhou consists of more than 0.8 million persons. The total migrant population in Guizhou province equalled around 2.3 million persons in 2011 (PFPC, 2011). Hence, the share of new generation migrants in the total migrant population in Guizhou is around 35 percent. It is somewhat lower than the most recent available estimate for China as a whole, which is nearly 45 percent (NPFPC, 2012). A possible explanation for this difference is that more younger migrants than older ones tend to prefer working in other provinces due to recent improvements in transportation infrastructure, better working and living conditions elsewhere, or other factors. More research on this issue is needed to assist the local government in designing appropriate policies to increase the share of young migrants in its population.

\section{[Figure 1]}

Migrants are defined in the survey as persons of working age (older than 15 years) who lodge or have settled in Guiyang City but do not have a Guiyang hukou (residence permit). They can either have a rural or an urban (non-Guiyang) hukou. We define new generation migrants in our survey data set as migrants who were born after 1980. This is consistent with earlier studies and policy papers on the issue. Children born since 1980 are all born under China's one-child policy. The generation born under this policy is often believed to be over-indulged and to have poorer social communication and cooperation skills than the older generation, but hard evidence is difficult to find. Figure 1 shows the age distribution of the migrants in our survey. It resembles a normal distribution, but a few age groups (particularly those aged 34-35 and 46-47) are under-represented. Out of the 1,048 interviewed migrants, 399 were born after 1980, i.e. 38 percent. Hence, the share of new generation migrants in our data set is close to the estimate that we derived above for Guiyang City as a whole.

\section{[Table 1]}

Table 1 presents the basic characteristics of the interviewed migrants, and compares these characteristics between the traditional and new generation. The share of Han in the migrant population equals 77 percent, which slightly exceeds its 70 percent share in the total population of Guizhou (source: NBSC, 2011). The share of females in the migrant population is close to 50 percent, while migrants with a rural hukou equal 87 percent of the interviewed migrants. We find no significant differences between the two generations in these indicators. The share of migrants coming from the own province, however, is significantly higher (80 percent) for the new generation as compared to the older one (72 percent). The new generation is evidently younger, is more likely to be single and less likely to have minor children. The average number of family members, however, is slightly higher for the new generation. The data further confirm findings from other studies (e.g. ACFTU, 2011; Liu, 2010; Wang, 2010) that the new generation is better educated: $31 \%$ of the new migrants have high school 
education or higher, but only $15 \%$ of the traditional generation. Not surprisingly, the average duration of the stay in Guiyang is much longer for the traditional generation. Almost twice as many migrants from the traditional generation have stayed longer than 5 years $(62 \%$, versus $33 \%$ for the new generation). Finally, more traditional generation migrants stay in rented houses than migrants from the new generation. This is understandable, because our survey results also show that $31 \%$ of the traditional generation knows the low-rent policy in Guiyang City, as compared to $25 \%$ of the new generation. Through their longer stay in Guiyang they are more aware of government policies which aim to solve housing problems of the poor.

[Table 2]

Now we turn to the occupational characteristics of migrants (Table 2). We first look at the categories of jobs they do. Job categories are defined according to the classification used by the Ministry of Human Resources and Social Security. The three most common job categories among migrant workers in Guiyang City are unit chiefs and managers, which includes owners of family run businesses (20\%), business and service personnel (30\%) and production and transportation workers (32\%). In contrast to NPFPC $(2011,2012)$ we do find some significant differences between the new generation and the traditional generation. New generation migrants are more likely to work as business and service personnel ( $40 \%$ as compared to $23 \%$ ), while migrants from the traditional generation are more likely to be unit chiefs or managers (22\% as compared to $18 \%)$ and to belong to the category 'other (including those who do not have a fixed job)' (18\% as compared to $10 \%$ ).

Table 2 also shows that as much as 44 percent of the interviewed migrants are self-employed or work in family businesses. Most wage earners are employed by private businesses. Only 9 percent of the migrants works in a state-owned or collectively owned enterprises. Again we do find some significant differences between the two generations. Migrants born in the 1980s and 1990s are more frequently employed by private enterprises, and less likely to be self-employed or find work in stateowned or collective enterprises, as compared to migrants born in the 1970 s or before. They also make more use of official labour channels for finding an urban job.

\section{[Table 3]}

The working conditions of the interviewed migrants in Guiyang City are shown in Table 3. The reported average monthly income of migrants equals 2,485 RMB ${ }^{1}$ Despite the differences in age, education and job categories between the two generations, there is not much difference in their average income levels. Also in terms of working hours per day, having a signed contract or not, receiving payments for extra work, and having experienced wage defaults or work disputes, the two groups do not differ significantly from each other. However, the results do show that the new generation has more insurances at work, receives significantly more on-the-job training, conducts less dangerous or toxic work, and receives more regular health checks than the traditional generation. So,

\footnotetext{
${ }^{1}$ The official exchange rate in August, 2011 was $6.4 \mathrm{RMB}=1$ USD.
} 
we do find some evidence of better working conditions among the new generation of migrants, as we hypothesized at the end of Section 2.

[Table 4]

Table 4 compares the incomes of the two generations of migrants per job category. It shows that the average income is slightly higher for the younger generation in each job category, but none of the differences is statistically significant (except for professional and teaching personnel, for which we have only 8 observations). Hence, the higher education of the new generation of migrants did not result in higher earnings for similar jobs at the time of the survey. The much longer experience of the traditional generation probably makes up for their lower level of education.

The analyses so far show some significant differences in education, occupational characteristics and working conditions between the two generations. Do these differences translate into differences in job attitudes, as suggested in the media and in some policy documents? We use our survey data to explore this question in more detail by focusing on four aspects: (1) job satisfaction (measured on a scale from 1 = very dissatisfied to 5 = very satisfied); (2) inclination to change jobs; (3) rights pursuing (reliance on government and law to pursue rights when there is a dispute at work); and (4) study in spare time.

[Table 5]

Table 5 shows the summary statistics of these four job attitude variables. A first noteworthy finding is that the level of job satisfaction is slightly higher among the new generation of migrants. The observed difference is statistically significant (at the 1 percent testing level). This finding contradicts public opinions that the new generation is more demanding and has higher requirements for living and working conditions, and is therefore less satisfied at work. The fact that our survey was held in one of the 49 cities where a pilot project on reducing labour market segregation was implemented, may at least partly explain this result.

The new generation migrants also seem to care more about their own rights at work, as they are less likely to give up their rights when there is a dispute. When they pursue their rights, they are much more likely to rely on law and government $(47 \%)$, while the traditional generation relies more on help from relatives and friends (62\%). Despite the higher job satisfaction of young migrants, they still seem to be very ambitious. We find in our survey that a larger share of young migrants is prone to change their jobs and studies in their spare time as compared to the old generation of migrants.

\section{Factors explaining job satisfaction}

One of the main outcomes of the direct comparisons in the previous section is the statistically significant higher job satisfaction of the new generation. In this section, we examine which factors 
contribute to the observed difference in job satisfaction between the two generations. To this end, we estimate the following equation:

$$
l S_{\tilde{i}}=c+I D C_{\tilde{i}}+\beta F C_{\tilde{i}}+\gamma E D_{i}+\delta O C_{\tilde{i}}+\theta W C_{\tilde{i}}+\varepsilon_{\tilde{i}} \quad \text { for } \mathrm{i}=1, \ldots, 1048
$$

where JS is job satisfaction, DC denotes a set of variables capturing demographic characteristics comprising age, gender, race, whether the migrant comes from Guizhou province, and whether the migrant has a rural hukou. FC is a set of family characteristics including the number of family members in the home village, marital status, and the number of minor children. Educational characteristics of the migrant are denoted by ED. We distinguish between migrants with only primary education, those with secondary education, and those with high school or higher. The occupational characteristics of the migrant are denoted by OC. It includes variables representing the job category, employment type and how the migrant found the job. The last set of explanatory variables represents working conditions (WC), which includes income, daily working hours, possession of written contract, wage default experiences, dispute at work, insurance at work, on-the-job training, employment in dangerous or toxic work, and regular health checks ${ }^{2}$. Finally, $\varepsilon$ represents the error term (with standard properties), while $c, \boldsymbol{\alpha}, \boldsymbol{\beta}, \boldsymbol{Y}, \boldsymbol{\delta}$ and $\boldsymbol{\theta}$ represent the (vectors of) unknown coefficients. Since job satisfaction is an ordinal variable, we use an ordered logit regression model to estimate equation (1).

Some of the explanatory variables in the model may be endogenous instead of exogenous variables. This is likely to be the case, for example, with the income variable. A higher monthly income may not only contribute to a higher level of job satisfaction; job satisfaction itself may also be an important factor in raising productivity and hence be positively related to the monthly income of a migrant worker. In our analysis we will not address the issue of causality. We attempt to examine the factors that are related to the existing difference in job satisfaction between the two generations of migrants, but will not try to unravel the more complex questions about direction of causality.

[Table 6]

We ran the regression model (1) for the whole sample of migrants, and for new and old generation migrants separately, to examine whether the factors influencing job satisfaction differ between the two generations. The results are shown Table 6. We will first discuss the results for the whole sample, and then compare the differences between the two generations.

One important finding, where our result deviates from that of earlier research (Clark et al., 1998; Bender et al., 2005), is that age and gender do not matter for job satisfaction. Hence, although the new generation of migrants has a higher job satisfaction than the traditional one, it is not the much younger age that seems to explain this finding. Instead, we find that working conditions play an important role in job satisfaction. Having a higher income, working fewer hours, absence of wage defaults, receiving on-the-job-training, doing no harmful or toxic work and having regular health checks

\footnotetext{
${ }^{2}$ Receiving payment for extra work is not included among the explanatory variables, because this would reduce the sample size by more than 60 percent.
} 
are all positively related (at a 5 percent testing level) to the level of job satisfaction of migrants in Guiyang City. Other important factors that we find in our analysis are working as a unit chief, manager, professional, technician, clerk or in related jobs (categories $1-3$ ) and having fewer young children.

To what extent do these contributing factors differ between the two generations of migrants? Because the new generation was born under the one-child policy, has a significantly higher level of education, and is assumed to be more aware of its own rights and less obedient, it may be expected that it derives its job satisfaction from other factors than the traditional generation. The regression results for each of the two generations separately are shown in the last two columns of Table 6.

Some interesting results show up, especially for working conditions. We find that the level of income is significantly related to the degree of job satisfaction of the old generation, but not to that of the young generation. One might argue that this result is caused by multicollinearity, because education, occupational characteristics and demographic characteristics are part of our model, but this is not the case. The variance inflation factor (VIF) of income in the new generation model is 1.45, while VIF $>5$ is commonly used as a rule of thumb for detecting multicollinearity. And dropping education, occupational characteristics and demographic characteristics from the model does not affect our conclusion $^{3}$. Instead of income, having a formal contract and doing no dangerous or toxic work are important factors in the degree of job satisfaction of young migrants, but not that of the older generation. Estimated coefficients for the non-income working conditions are larger in absolute value for the young generation. The only exception is on-the-job training ${ }^{4,5}$, which is significantly related to job satisfaction of the older generation but not the younger generation.

We also find that young migrants derive job satisfaction from different types of jobs than older migrants do. Young migrants working as business and service personnel or as production, transport equipment operators and related workers (categories 4 and 5) have significantly higher job satisfaction than those working in the other job categories. For older migrants, this is not the case. In fact, older migrants derive the highest job satisfaction from working in the first three job categories (as defined in Table 4).

We find some limited evidence that the way in which migrants obtain their jobs may matter for job satisfaction. Young migrants who get a job through the formal labour market have a lower job satisfaction (at a 10 percent significance level) than those who are introduced to a job by family or friends (or are self-employed). As regards to employment type, our results suggest that older migrants obtain positive job satisfaction from being self-employed or working in a family run business, whereas it has a negative impact on the job satisfaction of younger migrants. This may explain why fewer young migrants than older migrants are self-employed or work in family run businesses (see Table 2).

Although the age of a migrant does not significantly affect job satisfaction for the whole sample, we do find that age plays a role in the job satisfaction of older migrants. The estimated coefficients for age and age squared in the equation for the traditional generation indicates the presence of an inverted $\mathrm{U}$ -

\footnotetext{
${ }^{3}$ Results are available upon request from the authors.

${ }^{4}$ And for dispute at work, but the estimated coefficients are both not significantly different from zero.

${ }^{5}$ One-the-job training reflects the training that migrants received from their current employer. The survey questionnaire also contains a question about past training received before entering the present job. This variable does not significantly affect job satisfaction of both generations and is therefore not included in our analysis.
} 
shaped curve, with the highest job satisfaction obtained around the age of 48. Interestingly, this finding is opposite to the $U$-shaped curve that has been found in the international literature (see section 2). We further find that presence of young children in the home village affects especially the job satisfaction of young migrants in a negative way. A final noteworthy finding is that young Han migrants have higher job satisfaction than young migrants coming from other ethnic groups. Whether this is caused by discrimination at the work floor or by other factors, is an issue that certainly deserves more research.

Thus far we have found that young migrants have higher job satisfaction than older migrants, that the factors contributing to the job satisfaction of each generation are different, and that the two generations possess different quantities ('endowments') of some of these factors. This brings us to the question to what extent the higher job satisfaction of the new generation is related to differences in their valuation of the factors that contribute to job satisfaction or by differences in their endowments of these factors. We will use a Blinder-Oaxaca decomposition to answer this question. The method that we use is as follows (see e.g. Jann, 2008). Assume there are two groups, group A (= new generation) and group $B$ (= traditional generation), and that the outcome $Y$ (= job satisfaction) is predicted by the following equation:

$$
Y_{I}=X_{I}^{*} \beta_{I}+\varepsilon_{I^{s}} \quad E\left(\varepsilon_{l}\right)=0, \quad l \mid\{A, B\} .
$$

Then the predicted difference between group A and B can be decomposed into three parts ${ }^{6}$ :

- the differential caused by group differences in the regressors (the 'endowment effect'): $\left(E\left(X_{A}\right)-E\left(X_{B}\right)\right)^{\prime} \beta_{B}$,

- the differential caused by differences in the estimated coefficients: $E\left(X_{B}\right)^{\prime}\left(\beta_{A}-\beta_{B}\right)$, and

- an interaction term accounting for the fact that differences in endowments and coefficients exist simultaneously between the two groups: $\left(E\left(X_{A}\right)-E\left(X_{B}\right)\right)^{\prime}\left(\beta_{A}-\beta_{B}\right)$.

We only include the regressors which are significant in at least one of the three regressions (i.e. whole sample and two subsamples) reported in Table 6 when conducting the decomposition ${ }^{7}$.

[Table 7]

Table 7 shows the results of the decomposition analysis, with endowments, coefficients and interaction terms aggregated according to the groups of variables distinguished in equation (1). We find that only the first decomposition term, the endowments effect, has a significant impact. It explains $84.2 \%$ of the predicted difference in job satisfaction between the two generations. Among the endowments, especially the differences in working conditions contribute to the higher job satisfaction of the new generation of migrants (64.8\%). Differences in family characteristics are another factor that

\footnotetext{
${ }^{6}$ Using a decomposition expressed from the viewpoint of Group A, as we do here, or using a twofold composition (see e.g. Jann, 2008) leads to similar conclusions. Results for the twofold decomposition can be obtained from the authors upon request.

${ }^{7}$ We use linear regressions instead of ordered logit regressions when conducting the decomposition for job satisfaction. We do not include age, because age is used for dividing the sample into two groups.
} 
contributes positively $(21.9 \%)$. Differences in demographic characteristics and in occupational characteristics, on the other hand, do not significantly affect the difference in job satisfaction between the two groups. Nor do differences in the way that the two generations value their endowments play a significant role in explaining the higher level of job satisfaction of the young generation.

\section{Conclusion}

China is experiencing notable changes in rural-urban migration. Young, more educated migrants are increasingly playing a major role in both urbanization and economic development. Their attitudes towards working and living in the cities are different from those of the older generation. The destinations of migrants are also changing as a result of government policies and the global financial crisis. More migrants than before find jobs in medium and small size cities, which are often located in western and central China instead of the coastal region. In this paper we aim to contribute to the design of sustainable migration and urbanisation policies that recognize these new developments by providing insights into the characteristics, working conditions, job satisfaction and other job attitudes of the new generation of migrants, defined as those born in the 1980s and 1990s, as compared the traditional generation in a medium-size city in western China where labour market segmentation between migrants and urban workers is actively being reduced. To this end, we use survey data collected in August 2011 among 1,048 rural migrants in Guiyang City, Guizhou Province, to examine four research questions.

Firstly, we examine the extent to which socio-economic and occupational characteristics differ between the two generations of migrants and find a number a significant differences. Our data confirm findings from previous studies that the new generation is better educated. We further find important differences in occupational characteristics between the two generations. New generation migrants are more likely to work as business and service personnel and are more frequently employed by private enterprises, while migrants from the traditional generation are more likely to be unit chiefs or managers, and to be self-employed or work in state-owned or collective enterprises.

Secondly, we use our survey data to examine differences in working conditions and job attitudes between the new generation and traditional generation of migrants. Despite the differences in age, education and job categories between the two generations, we find that there is not much difference in their average income levels. This finding also holds when we take the types of jobs in which the two generations are employed into account. We do find, however, that the new generation of migrants has more insurance at work, receives significantly more on-the-job training, conducts less dangerous or toxic work, and receives more regular health checks than the traditional generation. Job attitudes also differ significantly between the two generations. In contrast to popular beliefs, we find that the level of job satisfaction is significantly higher among the new generation of migrants. Young migrants are also less likely to give up their rights when there is a dispute at work, and more likely to rely on law and government instead of relatives and friends in solving disputes. Despite the higher job satisfaction of 
young migrants, they seem to be more ambitious as they study more in their spare time and are more inclined to change job than the old generation of migrants.

Thirdly, we examine the factors that contribute to the higher degree of job satisfaction among the new generation of migrants. Contrary to previous findings in the international literature, we find that age and gender do not matter for job satisfaction of the young generation. Instead, working conditions play an important role. Among these, it is not so much the income level that matters for young migrants, but other working conditions. Having a formal contract and doing no dangerous or toxic work are important factors that provide job satisfaction to young migrants, but not to older migrants. In addition, young migrants derive job satisfaction from different types of jobs than older migrants do. Young migrants working as business and service personnel or as production, transport equipment operators and related workers have significantly higher job satisfaction than those working in the other job categories.

Using these results, we finally examine to what extent the observed differences in job satisfaction between the two generations is related to differences in endowments or to differences in the subjective valuations of factors that contribute to job satisfaction. Using a Blinder-Oaxaca decomposition, we conclude that it is mainly the difference in endowments that contribute to the higher job satisfaction of young migrants. Among the endowments, especially the differences in working conditions play an important role in the higher job satisfaction of the new generation of migrants. Differences in family characteristics are another factor that contributes positively to the job satisfaction differential.

The findings of our study have important implications for policy making as well as private enterprise management. They show that young migrants are not as dissatisfied with their jobs as is often believed. There remains scope, however, for further improving the job satisfaction of both older and younger migrants. Our findings suggest that the importance of income for job satisfaction is declining, and that other working conditions are becoming more and more important. These include not only the number of working hours, having insurances, receiving on-the-job-training and no wage defaults, but especially for the new generation also healthy work conditions and having a signed contract. Improving such working conditions is expected to contribute both to the welfare of rural migrants and to the productivity of the enterprises in which they are employed. 


\section{References}

All-China Federation of Trade Unions (ACFTU). 2011. Research Report on New Generation of Migrant Workers, (online: http://news.xinhuanet.com/politics/2010-06/21/c_12240721.htm) July 11, Beijing. (Chinese)

Bender, K.A., Donohue, S.M. and Heywood, J.S.. 2005. Job satisfaction and gender segregation, Oxford Economic Papers 57: 479-496.

Cai, F., Wang, D., and Zhang, H. 2010. Employment Effectiveness of China's Economic Stimulus Package. China \& World Economy 18: 33-46.

Cao, X. and Lin, J. 2010. Policy paper promises more efforts for rural-urban integration. Special report: No.1 Document targets rural-urban development. (online: http://news.xinhuanet.com/english2010/china/2010-02/01/c 13158156.htm), February 1, Beijing, Xinhua.

Cascio, W.F. and Boudreau, J.W. 2008. Investing in People: Financial Impact of Human Resource Initiatives, New Jersey: Pearson Education.

Chen, Z., Lu M. and Sato, H. 2009. Who entered high-wage industries? The role of social network, hukou and labor productivities. Economic Research Journal 10:121-131. (Chinese)

Clark, A., Georgellis, Y., and Sanfey, P. 1998. Job Satisfaction, Wage Changes and Quits: Evidence from Germany, Research in Labour Economics 17: 95-122.

Fine, B.. Labor Market Theory: A Constructive Reassessment. London and New York: Routledge, 1998.

Fleetwood S. 2011. Sketching a socio-economic model of labour market. Cambridge Journal of Economics 35: 15-38.

Freeman, R., Kruse., D. and Blasi, J.. (2008). The same yet different: worker reports on labour practices and outcomes in a single firm across countries, Labour Economics 15: 750-771.

Guiyang Municipal Government. 2011. The $12^{\text {th }}$ Five-Year Plan of Economic and Social Development of Guiyang City, Guiyang, China. (online: http://www.gygov.gov.cn/gygov/1442564757562327040/20110413/290065.html). (Chinese)

Gurin, G., Veroff, J. and Feld, S.. 1960. Americans View Their Mental Health, New York: Basic Books.

Hsu, S., Jiang, S., and Heyward, H. 2010.The global crisis' impact upon China's rural migrants, Journal of Current Chinese Affairs 2:167-185.

Huang, J., Zhi, H., Huang, Z., Rozelle, S., and Giles, J. 2011. The Impact of the Global Financial Crisis on Off-farm Employment and Earnings in Rural China. World Development 39: 797-807.

Jann, B. 2008. A Stata implementation of the Blinder-Oaxaca decomposition. ETH Zurich Sociology Working Paper No. 5. Zurich, Switzerland: Swiss Federal Institute of Technology.

Katz, D. 1960. The functional study of attitudes. Public Opinion Quarterly 24:163-204.

Li, P. and Li, W. 2007. Economic status and social attitudes of migrant workers in China, China \& World Economy 15(4):1-16.

$\mathrm{Li}, \mathrm{P}$. and Tian, F. 2011. The new generation of migrant workers: social attitudes and behavioural choices, Chinese Journal of Sociology 31(3):1-23. (Chinese) 
Li, S. 2008. Rural Migrant Workers in China: Scenario, Challenges and Public Policy. Working Paper No. 89, Policy Integration and Statistics Department, International Labour Office, Geneva.

Li, Y.L. 2012. Political economy interpretations on labor market segmentation of China. Science Economy Society 30(127): 64-68. (Chinese)

Liu, C. 2010. The characteristics of new-generation migrant workers and the challenges to citizenization. Population Research 34(2): 34-39. (Chinese)

Liu, Y., Li, Z. and Breitung, W. 2012. The social networks of new-generation migrants in China's urbanized villages: A case study of Guangzhou. Habitat International 36: 192-200.

Liu, Y. and Zhou, F. 2011. The new generation farmer workers of Guizhou province: accommodation to the urban life and analysis of social psychology, Guiyang (China): Journal of Guizhou University for Nationalities (Philosophy and Social Science) (3):77-81. (Chinese)

Locke, E.A. 1976. The nature and causes of job satisfaction. In: M.D. Dunnette (Ed.), Handbook of industrial \& organizational psychology, Chicago: Rand-McNally, Pp.1297-1349.

Lu, Z. and Deng, X. 2011. China's western development strategy: Policies, effects and prospects. MPRA Paper no. 35201. http://mpra.ub.uni-muenchen.de/35201/

Meng, X. and Zhang, J.S. 2001. Two-tier labor market in urban China: occupational, segregation and wage differentials between urban residents and rual migrants in Shanghai. Journal of Comparative Economics 29(3): 485-504.

Ministry of Human Resources and Social Security of PR China (MHRSS). 2008. Announcement on Effective Implementation of the Government's Program for Skill Training and Re-employment of Rural Labourers in 2008, MHRSS public announcement No.123. (Chinese)

National Bureau of Statistics of China (NBSC). 2010. 2009 Monitoring Report of Migrant Workers, (online: www.stats.gov.cn/tjfx/fxbg/t20100319_402628281.htm), April 17, Beijing. (Chinese)

National Bureau of Statistics of China (NBSC). 2011. China Statistical Yearbook 2011, Beijing: China

Statistics Press. (online: http://www.stats.gov.cn/english/statisticaldata/yearlydata/\#).

National Bureau of Statistics of China (NBSC). 2012. Statistical Communiqué on the 2011 National Economic and Social Development. (online:

www.stats.gov.cn/english/newsandcomingevents/t20120222 402786587.htm), February 22, Beijing.

National Population and Family Planning Commission of China (NPFPC). 2010. Opinions on the experiments of innovating services and management system and promoting the equalization of basic public services for the floating population including the implementation of the family planning program, No.69, (online:

http://www.chinapop.gov.cn/rdzt//drkfwjdh/fwjdhgddt/201104/t20110418_356224.html), circulated by People's Government of Guiyang Municipality. (Chinese)

National Population and Family Planning Commission of China (NPFPC). 2011. Report on China's migrant population development, Beijing: China Population Publishing House. (Chinese)

National Population and Family Planning Commission of China (NPFPC). 2012. Report on China's migrant population development, Beijing: China Population Publishing House. (Chinese) 
Population and Family Planning Commission of Guiyang (PFPC). 2011. IC card credited to million migrants by Guiyang municipality, (online: http://rkjsj.gygov.gov.cn/rkjsj/3386991693294206976/20111017/312544.html). (Chinese)

Pun, N. and Lu, H. 2010. Unfinished proletarianization: self, anger and class action among the second generation of peasant-workers in present-day China, Modern China 36(5): 493-519.

Qian, W. and Zhang, L. 2009. Work and family relations and their effects on job satisfaction of rural migrants - evidence of migrant workers with family emigrating to Hangzhou, Ningbo and Wenzhou, Chinese Rural Economy, 5: 70-78. (Chinese)

Rogers, J., Clow, K., and Kash, T. 1994. Increasing Job Satisfaction of Service Personnel, Journal of Service Management 8:14-26.

Sun, Z. 2011. Education, reservation wages and wage inequality between different registered residences of migrant workers. Journal of Agrotechnical Economics 12: 70-78.

Wang, C. 2003. The social identities of new generations of migrants from China's rural areas. In Social Science in China. Beijing: Chinese Academy of Social Science.

Wang, C. 2010. Study on social integration of new generation migrant workers in cities. Population Research 34(2): 31-34. (Chinese)

Wang, F. 2010. Human capital, labor market segmentation and income distribution. Chinese Journal of Sociology 1:109-126. (Chinese)

Wang, T. and Cui, X. How does industry influence income distribution results of HLM analysis. Social Science in China 5:165-181. (Chinese)

Wang, Y.K and Luo C.L. 2012. China's labor market development based on economic transform. Journal of Renmin University of China 3:75-82. (Chinese)

Wei, Y. 2007. For rural-urban migrant workers: What should China's government do? 7th Berlin Roundtables on Trans-nationality on Migration into Cities; Berlin, Germany.

Wong, S. 2010. Decoding the new generation of Chinese migrant workers, EU-China Civil Society Forum, Hintergrundinformationen 8/2010-1, September. www.eu-china.net

Yeung, Y. M. and Shen, J. (eds.). 2004. Developing China's West: A Critical Path to Balanced National Development. Hong Kong: Chinese University Press of Hong Kong.

Yue, Z., Li, S., Feldman, M.W., and Du H. 2009. Wandering at crossroad: a comparative study on development will of two generations of migrant rural workers. Population and Economics 6: 58-66. (Chinese)

Yu, T.F. 2012. Spatial-temporal features and influential factors of the China urban floating population growth. Chinese Journal of Population Science 4: 47-58. (Chinese) 


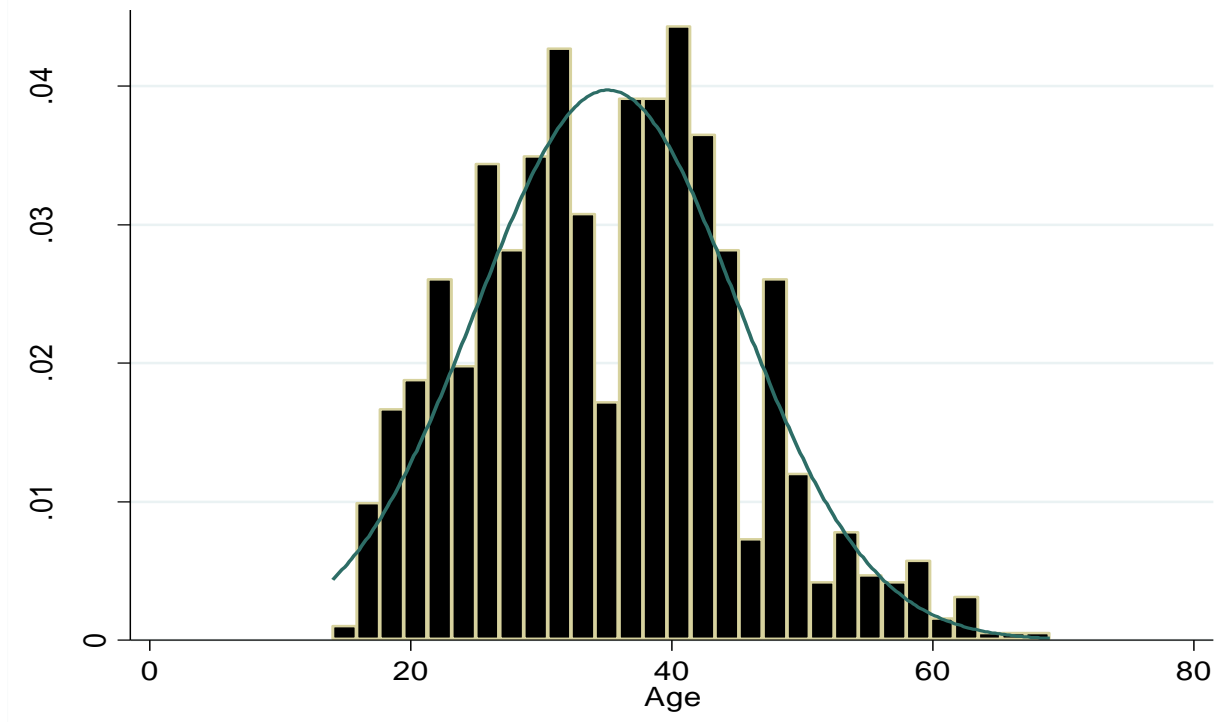

Figure 1. Age distribution of the interviewed migrants 
Table 1. Basic characteristics of the new generation (NG) and traditional generation (TG) of migrants

\begin{tabular}{|c|c|c|c|c|c|}
\hline \multirow[b]{2}{*}{ Demographic factors } & \multirow[b]{2}{*}{ Obs. } & \multicolumn{3}{|c|}{ Mean (Standard Deviation) } & \multirow{2}{*}{$z$} \\
\hline & & $\begin{array}{l}\text { Whole } \\
\text { sample }\end{array}$ & TG & $N G$ & \\
\hline Number of observations & & 1048 & 649 & 399 & \\
\hline Ethnicity (Han) & 1048 & 0.77 & 0.77 & 0.77 & -0.15 \\
\hline Gender (Male) & 1048 & $\begin{array}{c}0.51 \\
(0.50)\end{array}$ & $\begin{array}{c}0.52 \\
(0.50)\end{array}$ & $\begin{array}{c}0.48 \\
(0.50)\end{array}$ & -1.42 \\
\hline Hukou (Rural resident $=1$ ) & 1048 & $\begin{array}{c}0.87 \\
(0.33)\end{array}$ & $\begin{array}{c}0.89 \\
(0.32)\end{array}$ & $\begin{array}{c}0.85 \\
(0.35)\end{array}$ & -1.48 \\
\hline Intra-province migrant (Native) & 1048 & $\begin{array}{c}0.75 \\
(0.43)\end{array}$ & $\begin{array}{c}0.72 \\
(0.45)\end{array}$ & $\begin{array}{c}0.80 \\
(0.40)\end{array}$ & $3.14^{* * *}$ \\
\hline Age & 1048 & $\begin{array}{c}35 \\
(10.05)\end{array}$ & $\begin{array}{c}41 \\
(6.99)\end{array}$ & $\begin{array}{c}25 \\
(4.18)\end{array}$ & $-27.22^{\star \star *}$ \\
\hline Marital status ( Single) & 1048 & $\begin{array}{c}0.17 \\
(0.37)\end{array}$ & $\begin{array}{c}0.03 \\
(0.18)\end{array}$ & $\begin{array}{c}0.39 \\
(0.49)\end{array}$ & $15.04^{* * *}$ \\
\hline Family members & 1048 & $\begin{array}{c}4.47 \\
(1.47)\end{array}$ & $\begin{array}{c}4.38 \\
(1.42)\end{array}$ & $\begin{array}{c}4.60 \\
(1.54)\end{array}$ & $2.40^{* *}$ \\
\hline Minor child in family & 1047 & $\begin{array}{c}0.59 \\
(0.49) \\
\end{array}$ & $\begin{array}{c}0.69 \\
(0.46)\end{array}$ & $\begin{array}{c}0.41 \\
(0.49)\end{array}$ & $-8.99^{* * *}$ \\
\hline Education & 1048 & $\begin{array}{c}0.10 \\
(0.30)\end{array}$ & $\begin{array}{c}0.14 \\
(0.35)\end{array}$ & $\begin{array}{c}0.03 \\
(0.16)\end{array}$ & $-6.08^{* * *}$ \\
\hline primary school & 1048 & $\begin{array}{c}0.27 \\
(0.44)\end{array}$ & $\begin{array}{c}0.33 \\
(0.47)\end{array}$ & $\begin{array}{c}0.17 \\
(0.38)\end{array}$ & $-5.45^{* \star *}$ \\
\hline secondary school & 1048 & $\begin{array}{c}0.42 \\
(0.49)\end{array}$ & $\begin{array}{c}0.38 \\
(0.49)\end{array}$ & $\begin{array}{c}0.49 \\
(0.50)\end{array}$ & $3.44^{* * *}$ \\
\hline high school & 1048 & $\begin{array}{l}0.15 \\
0.36)\end{array}$ & $\begin{array}{c}0.12 \\
(0.32)\end{array}$ & $\begin{array}{c}0.21 \\
(0.41)\end{array}$ & $3.98^{\star \star \star}$ \\
\hline college or above & 1048 & $\begin{array}{c}0.06 \\
(0.23)\end{array}$ & $\begin{array}{c}0.03 \\
(0.17)\end{array}$ & $\begin{array}{c}0.10 \\
(0.30)\end{array}$ & $4.84^{* \star *}$ \\
\hline Duration of stay & 1048 & $\begin{array}{c}0.11 \\
(0.31)\end{array}$ & $\begin{array}{c}0.06 \\
(0.24)\end{array}$ & $\begin{array}{c}0.18 \\
(0.38)\end{array}$ & $5.83^{* \star *}$ \\
\hline Longer than 5 year & 1048 & $\begin{array}{c}0.51 \\
(0.50)\end{array}$ & $\begin{array}{c}0.62 \\
(0.49)\end{array}$ & $\begin{array}{c}0.33 \\
(0.47)\end{array}$ & $-9.32^{* * *}$ \\
\hline Living condition Free shed or quarters & 1043 & $\begin{array}{c}0.13 \\
(0.34)\end{array}$ & $\begin{array}{c}0.11 \\
(0.31)\end{array}$ & $\begin{array}{c}0.16 \\
(0.37)\end{array}$ & $2.20^{* *}$ \\
\hline Rented house & 1043 & $\begin{array}{c}0.81 \\
(0.39)\end{array}$ & $\begin{array}{c}0.83 \\
(0.38)\end{array}$ & $\begin{array}{c}0.78 \\
(0.42)\end{array}$ & $-1.95^{* *}$ \\
\hline Own house & 1043 & $\begin{array}{c}0.06 \\
(0.24)\end{array}$ & $\begin{array}{c}0.06 \\
(0.23)\end{array}$ & $\begin{array}{c}0.06 \\
(0.24)\end{array}$ & 0.11 \\
\hline
\end{tabular}

Notes: Standard deviations are in parentheses. The last column reports the $z$-value from testing two samples are from populations with the same distribution using the

Wilcoxon rank-sum test. ${ }^{* *}$ significant at $1 \%$ level; ${ }^{* *}$ significant at $5 \%$ level; ${ }^{*}$ significant at $10 \%$ level. 
Table 2. Occupational characteristics of the new generation (NG) and traditional generation (TG) of migrants

\begin{tabular}{|c|c|c|c|c|c|}
\hline & \multirow{2}{*}{ Obs. } & \multicolumn{3}{|c|}{ Mean (Standard Deviation) } & \multirow{2}{*}{ z } \\
\hline & & Whole sample & $\mathrm{TG}$ & NG & \\
\hline Job category & 1046 & & & & \\
\hline Unit chief and manager & & $0.20(0.40)$ & $0.22(0.41)$ & $0.18(0.38)$ & $-1.61^{\star}$ \\
\hline Professional and technical personnel & & $0.01(0.09)$ & $0.01(0.10)$ & $0.01(0.07)$ & -0.77 \\
\hline Clerk and related workers & & $0.03(0.16)$ & $0.03(0.17)$ & $0.02(0.13)$ & -1.32 \\
\hline Business and service personnel & & $0.30(0.46)$ & $0.23(0.42)$ & $0.40(0.49)$ & $5.78^{\times \pi \times}$ \\
\hline $\begin{array}{r}\text { Production, transport equipment operators } \\
\text { and related workers }\end{array}$ & & $0.32(0.47)$ & $0.33(0.47)$ & $0.29(0.46)$ & -1.27 \\
\hline Other (incl. no fixed job) & & $0.15(0.36)$ & $0.18(0.38)$ & $0.10(0.31)$ & $-3.19^{* * *}$ \\
\hline Type of employment & 1044 & & & & \\
\hline Self-employed or family business & & $0.44(0.50)$ & $0.46(0.50)$ & $0.40(0.49)$ & $-1.88^{*}$ \\
\hline State owned or collectively owned & & $0.09(0.28)$ & $0.10(0.30)$ & $0.06(0.24)$ & $-2.21^{* *}$ \\
\hline Private enterprise & & $0.47(0.50)$ & $0.44(0.50)$ & $0.54(0.50)$ & $3.12^{\pi \times \pi}$ \\
\hline Job hunting method & 1019 & & & & \\
\hline Introduced by relatives or friends & & $0.52(0.50)$ & $0.54(0.50)$ & $0.49(0.50)$ & -1.59 \\
\hline Labour market & & $0.45(0.50)$ & $0.43(0.50)$ & $0.49(0.50)$ & $2.03^{\pi \pi}$ \\
\hline Self-employed & & $0.03(0.16)$ & $0.03(0.38)$ & $0.02(0.13)$ & -1.35 \\
\hline
\end{tabular}

Notes: Standard deviations are in the parentheses. The last column reports the $z$-value from testing two samples are from populations with the same distribution using the Wilcoxon rank-sum test. ${ }^{* *}$ significant at $1 \%$ level; ** significant at $5 \%$ level; * significant at $10 \%$ level. 
Table 3. Working conditions of the new generation (NG) and traditional generation (TG) of migrants

\begin{tabular}{|c|c|c|c|c|c|}
\hline & \multirow{2}{*}{ Obs. } & \multicolumn{3}{|c|}{ Mean (Standard Deviation) } & \multirow{2}{*}{ z } \\
\hline & & Whole sample & TG & NG & \\
\hline Income per month (RMB) & 1040 & 2485 (3044) & 2427 (3063) & $2581(3014)$ & 0.96 \\
\hline Working hours per day & 1042 & $9.51(2.23)$ & $9.58(2.26)$ & $9.38(2.18)$ & -1.77 \\
\hline Signing contract (signed=1) & 896 & $0.34(0.48)$ & $0.33(0.47)$ & $0.37(0.48)$ & 1.70 \\
\hline Defaulted on wage & 914 & $0.09(0.29)$ & $0.08(0.28)$ & $0.10(0.30)$ & 0.62 \\
\hline Receiving payment for extra work & 411 & $0.76(0.43)$ & $0.78(0.41)$ & $0.74(0.44)$ & -1.06 \\
\hline Dispute at work & 1048 & $0.48(0.50)$ & $0.46(0.50)$ & $0.51(0.50)$ & 1.56 \\
\hline Insurance at work ${ }^{1}$ & 959 & $0.25(0.43)$ & $0.22(0.42)$ & $0.29(0.45)$ & $2.34^{\pi *}$ \\
\hline On-the-job training ${ }^{2}$ & 1047 & $0.41(0.49)$ & $0.35(0.48)$ & $0.51(0.50)$ & $5.01^{\pi \times \pi}$ \\
\hline Health & 1048 & & & & \\
\hline Dangerous or toxic work & & $0.22(0.41)$ & $0.25(0.43)$ & $0.18(0.38)$ & $-2.60^{x \times x}$ \\
\hline Regular health check & & $0.38(0.49)$ & $0.32(0.47)$ & $0.47(0.50)$ & $4.88^{\pi \times \pi}$ \\
\hline
\end{tabular}

Notes: Standard deviations are in the parentheses. The last column reports the $z$-value from testing two samples are from populations with the same distribution using the Wilcoxon rank-sum test. ${ }^{* \star *}$ significant at $1 \%$ level; ** significant at $5 \%$ level; * significant at $10 \%$ level.

${ }^{1}:$ Unemployment insurance, medical insurance and pension scheme

${ }^{2}$ : Training received from current employer 
Table 4. Incomes per job category of the new generation (NG) and traditional generation (TG) of migrants

\begin{tabular}{|c|c|c|c|c|c|}
\hline \multirow{2}{*}{ Job categories } & \multirow{2}{*}{ Description } & \multirow{2}{*}{ No. } & \multicolumn{2}{|c|}{ Income (RMB) } & \multirow{2}{*}{$z$} \\
\hline & & & TG & NG & \\
\hline $\begin{array}{l}\text { Unit chief and } \\
\text { manager }\end{array}$ & $\begin{array}{l}\text { Including owner of self-running } \\
\text { business, manager in the company. }\end{array}$ & 210 & $\begin{array}{l}3300 \\
(5384)\end{array}$ & $\begin{array}{c}3684 \\
(5419)\end{array}$ & 0.88 \\
\hline $\begin{array}{l}\text { Professional and } \\
\text { technical personnel }\end{array}$ & Including teacher and accountant. & 8 & $\begin{array}{l}2042 \\
(776)\end{array}$ & $\begin{array}{c}10500 \\
(10607)\end{array}$ & $1.84^{*}$ \\
\hline $\begin{array}{l}\text { Clerk and related } \\
\text { workers }\end{array}$ & $\begin{array}{l}\text { Including secretary or assistant in the } \\
\text { company, safeguard in policy station, } \\
\text { and dispatcher of travel agency, etc. }\end{array}$ & 27 & $\begin{array}{l}1392 \\
(1121)\end{array}$ & $\begin{array}{c}1843 \\
(1450)\end{array}$ & 1.34 \\
\hline $\begin{array}{l}\text { Business and } \\
\text { service personnel }\end{array}$ & $\begin{array}{l}\text { Including service attendant in } \\
\text { restaurant, sales staff and cashier in the } \\
\text { supermarket and shops, cook, barber, } \\
\text { cleaning staff, nurse, tailor, porter, } \\
\text { warehouse and logistics staff etc. }\end{array}$ & 313 & $\begin{array}{l}1584 \\
(1494)\end{array}$ & $\begin{array}{c}1774 \\
(1676)\end{array}$ & $3.27^{* \star *}$ \\
\hline $\begin{array}{l}\text { Production, } \\
\text { transport equipment } \\
\text { operators and } \\
\text { related Workers }\end{array}$ & $\begin{array}{l}\text { Including construction worker, driver, } \\
\text { factory worker, installment workers, } \\
\text { repairing and maintenance workers, etc. }\end{array}$ & 331 & $\begin{array}{l}2742 \\
(2396)\end{array}$ & $\begin{array}{c}2996 \\
(1904)\end{array}$ & 1.60 \\
\hline Other & Including those who have no fixed job. & 157 & $\begin{array}{l}2103 \\
(1299)\end{array}$ & $\begin{array}{c}2449 \\
(2395)\end{array}$ & 0.50 \\
\hline Total/average & & 1046 & $\begin{array}{c}2427 \\
(3063)\end{array}$ & $\begin{array}{c}2581 \\
(3014)\end{array}$ & 0.96 \\
\hline
\end{tabular}

Notes: Standard deviations are in parentheses. The last column reports the $z$-value from testing two samples are from populations with the same distribution using the Wilcoxon rank-sum test. Jobs are divided into six categories based on the Classification of Occupations in Labor Market and its Code (LB501-2002), issued by the Ministry of Human Resources and Social Security of China. 
Table 5. Job attitudes of the new generation (NG) and traditional generation (TG) of migrants

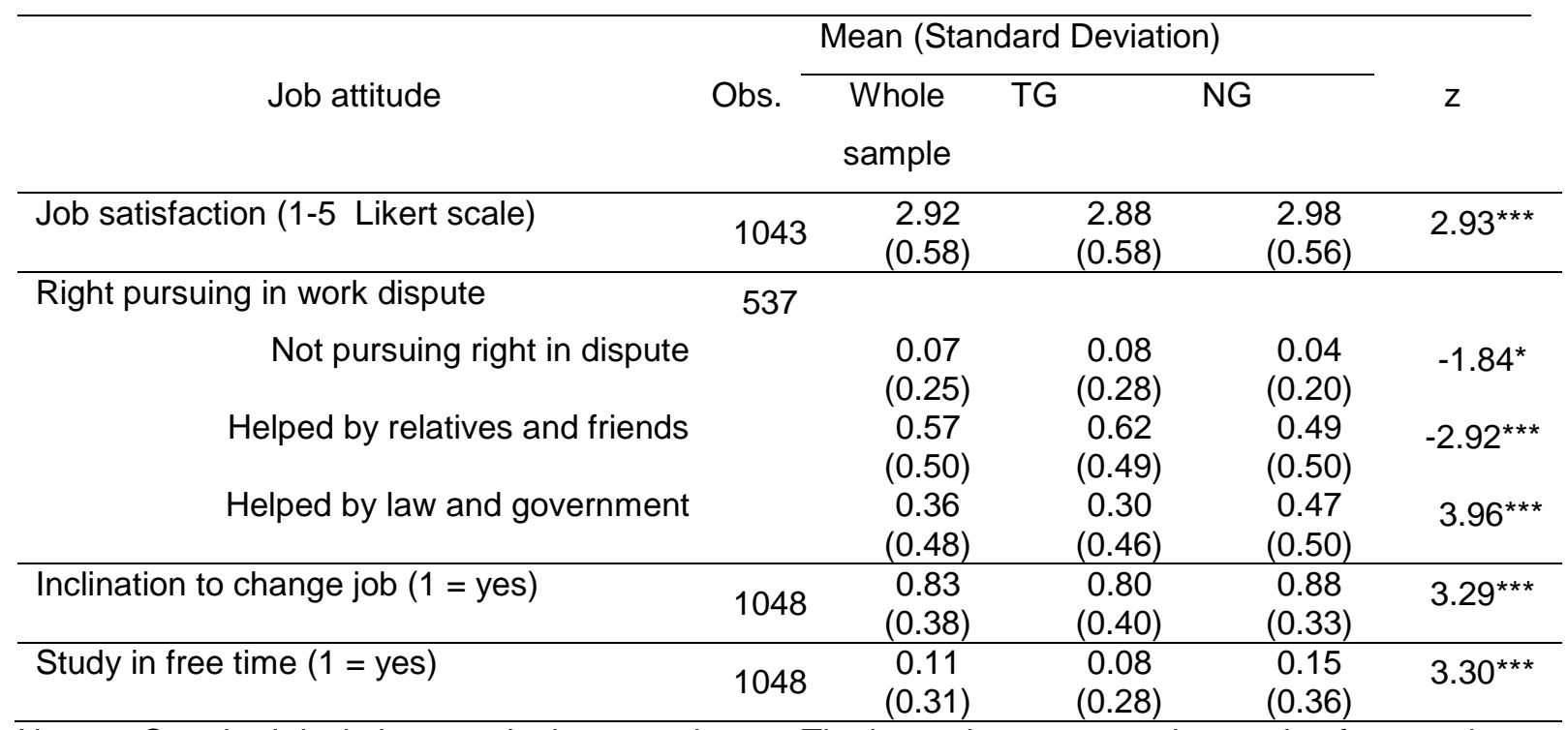

Notes: : Standard deviations are in the parentheses. The last column reports the z-value from testing two samples are from populations with the same distribution using the Wilcoxon rank-sum test.

${ }^{* * *}$ significant at $1 \%$ level; ${ }^{* *}$ significant at $5 \%$ level; * significant at $10 \%$ level. 
Table 6. Regression results for job satisfaction, ordered logit model

\begin{tabular}{lcccc}
\hline & \multicolumn{3}{c}{ Job satisfaction } \\
\cline { 2 - 5 } & $\begin{array}{c}\text { Whole } \\
\text { sample } \\
(1)\end{array}$ & $\begin{array}{c}\text { New } \\
\text { generation } \\
(2)\end{array}$ & $\begin{array}{c}\text { Traditional } \\
\text { generation } \\
(3)\end{array}$ & $\begin{array}{c}\text { p-value } \\
(4)\end{array}$ \\
\hline Demographic characteristics & & & & \\
Ethnicity (Han) & 0.29 & $0.573^{*}$ & 0.159 & 0.246 \\
& $(0.176)$ & $(0.309)$ & $(0.226)$ & \\
Gender (Male) & & & & \\
Age & -0.065 & -0.13 & -0.055 & 0.838 \\
Age2/100 & $(0.163)$ & $(0.270)$ & $(0.216)$ & 0.287 \\
& 0.009 & -0.141 & $0.270^{\star *}$ & \\
Intra-province migrant & $(0.055)$ & $(0.354)$ & $(0.129)$ & 0.378 \\
& -0.004 & 0.402 & $-0.279^{\star}$ & \\
Rural hukou & $(0.072)$ & $(0.719)$ & $(0.145)$ & \\
& & & & \\
& & & & \\
& -0.044 & -0.407 & 0.081 & 0.225 \\
& $(0.181)$ & $(0.333)$ & $(0.224)$ & \\
& -0.385 & -0.335 & -0.438 & 0.853 \\
& $(0.248)$ & $(0.404)$ & $(0.327)$ & \\
\hline
\end{tabular}

\section{Family characteristics}

Married (or divorced)

$\begin{array}{cccc}-0.025 & 0.009 & 0.305 & 0.676 \\ (0.271) & (0.355) & (0.551) & \end{array}$

Family members

$\begin{array}{cccc}0.004 & 0.100 & (0.056) & 0.154 \\ (0.051) & (0.083) & (0.067) & \end{array}$

Minor children

\begin{tabular}{llll}
$-0.420^{* *}$ & $-0.633^{*}$ & $(0.353)$ & 0.54 \\
$(0.185)$ & $(0.352)$ & $(0.227)$ & \\
\hline
\end{tabular}

\begin{tabular}{lcccc} 
Education & & & & \\
Primary school & 0.298 & 0.647 & 0.184 & 0.631 \\
& $(0.269)$ & $(0.747)$ & $(0.297)$ & \\
Secondary school & 0.402 & 0.415 & 0.344 & 0.94 \\
& $(0.265)$ & $(0.720)$ & $(0.299)$ & \\
High school and higher & 0.409 & 0.743 & 0.25 & 0.628 \\
& $(0.315)$ & $(0.762)$ & $(0.387)$ & \\
\hline Occupational characteristics & & & & \\
& & & & 0.799 \\
First three job categories & $0.716^{* *}$ & $0.822^{*}$ & $0.663^{\star *}$ & \\
& $(0.256)$ & $(0.477)$ & $(0.320)$ & 0.04 \\
$\begin{array}{l}\text { Business and service } \\
\text { personnel }\end{array}$ & 0.278 & $1.033^{* *}$ & -0.125 &
\end{tabular}


Production, transport

$(0.240)$

$(0.437)$

(0.304)

equipment operators and

related workers

0.100

$1.010^{\star *}$

$-0.288$

0.029

Job through formal labour

$(0.236)$

$(0.457)$

$(0.287)$

market

$-0.209$

$-0.463^{*}$

(0.150)

$(0.257)$

0.215

Self-employed or family

business

$0.031-1.239^{\text {** }}$

$-0.046$

(0.194)

(0.302)

(0.594)

$0.649^{*}$

0.009

State owned or collectively

owned

$0.256 \quad 0.186$

(0.363)

(0.177)

(0.300)

0.320

0.714

\section{Working conditions}

Income (In)

$\begin{array}{lccc}0.405^{\star *} & 0.303 & 0.465^{\star *} & 0.606 \\ (0.127) & (0.223) & (0.161) & \end{array}$

Working hours

$\begin{array}{ccc}-0.140^{\star * *} & -0.179^{* *} & -0.132^{\star *} \\ (0.036) & (0.061) & (0.047)\end{array}$

0.551

Signed contract

$\begin{array}{cccc}0.333 & 0.615 & 0.106 & 0.315 \\ (0.212) & (0.383) & (0.268) & \end{array}$

Defaulted on wage

$\begin{array}{llll}-0.672^{* *} & -1.022^{* *} & -0.638^{*} & 0.553 \\ (0.261) & (0.450) & (0.345) & \end{array}$

Insurance at work
0.188
0.358
0.129
0.655
(0.222)
(0.379)
(0.284)

Dispute at work
0.134
0.112
0.192
(0.161)
(0.282)
(0.205)

0.824

On-the-job training

$\begin{array}{cccc}0.565^{* * *} & 0.079 & 0.836^{* * *} & 0.028 \\ (0.168) & (0.281) & (0.216) & \end{array}$

Dangerous or toxic work
$-0.472^{* *}$
$-0.814^{\star \star}$
$-0.329$
0.331
(0.195)
(0.369)
$(0.241)$

Regular health checks

\begin{tabular}{lcccc} 
& $0.605^{\star * *}$ & $0.701^{* *}$ & $0.626^{* *}$ & 0.835 \\
& $(0.171)$ & $(0.288)$ & $(0.221)$ & \\
\hline _cut1 & $-2.880^{*}$ & -5.832 & 3.939 & 0.094 \\
& $(1.506)$ & $(4.593)$ & $(3.214)$ & \\
_cut2 & 0.73 & -1.456 & $7.401^{* *}$ & 0.121 \\
& $(1.464)$ & $(4.481)$ & $(3.201)$ & \\
_cut3 & $5.223^{\star * *}$ & 3.514 & $11.854^{* * *}$ & 0.145 \\
& $(1.476)$ & $(4.489)$ & $(3.230)$ & \\
_cut4 & $7.097^{\star * *}$ & 5.572 & $13.634^{* * *}$ & 0.159
\end{tabular}




\begin{tabular}{lccc} 
& $(1.496)$ & $(4.505)$ & $(3.244)$ \\
\hline VIF income $(\operatorname{In})$ & 1.33 & 1.45 & 1.33 \\
R-squared & 165.31 & 94.29 & 99.38 \\
N. of Obs. & 1006 & 386 & 620 \\
\hline
\end{tabular}

Notes: Note: Standard errors are in parentheses. The last column reports the $p$-values from testing the equality of the coefficients in Column (2) and (3).

${ }^{* * *}$ significant at $1 \%$ level; ${ }^{* *}$ significant at $5 \%$ level; * significant at $10 \%$ level.

${ }^{1}$ : Unit chief and manager, professional and technical personnel, and clerk and related worker (see Table 4) 
Table 7. Blinder-Oaxaca decomposition of difference in job satisfaction between new and traditional generation of migrants

\begin{tabular}{lccc}
\hline Differential & & & \\
$\begin{array}{l}\text { Predicted difference between } \\
\text { the two generations }\end{array}$ & $0.112^{* *}$ & & \\
\hline & $(100 \%)$ & Coefficients & Interaction \\
Demographic characteristics & Endowments & 0.062 & 0.000 \\
& 0.000 & $(55.70 \%)$ & $(0.17 \%)$ \\
Family characteristics & $(0.12 \%)$ & 0.031 & -0.013 \\
& $0.025^{*}$ & $(27.49 \%)$ & $(-11.45 \%)$ \\
Occupational characteristics & $(21.92 \%)$ & 0.022 & 0.012 \\
& -0.003 & $(19.33 \%)$ & $(11.09 \%)$ \\
Working conditions & $(-2.68 \%)$ & -0.174 & -0.006 \\
& $0.073^{\star * *}$ & $(-155.30 \%)$ & $(-5.78 \%)$ \\
Constant & $(64.84 \%)$ & 0.084 & - \\
& - & $(74.56 \%)$ & -0.007 \\
Total & & 0.024 & $(-5.97 \%)$ \\
\hline
\end{tabular}

${ }^{* * *}$ significant at $1 \%$ level; ** significant at $5 \%$ level; * significant at $10 \%$ level. 
Appendix A: First stage regressions of Blinder-Oaxaca decomposition

\begin{tabular}{|c|c|c|}
\hline & $\begin{array}{l}\text { Traditional } \\
\text { generation }\end{array}$ & $\begin{array}{c}\text { New } \\
\text { generation }\end{array}$ \\
\hline & Coef./S.D. & Coef./S.D. \\
\hline Ethnicity (Han) & 0.056 & $0.138^{* *}$ \\
\hline & $(0.053)$ & $(0.064)$ \\
\hline Minor children & $-0.085^{*}$ & -0.04 \\
\hline & $(0.049)$ & $(0.057)$ \\
\hline First three job categories & $0.174^{* *}$ & 0.143 \\
\hline & $(0.074)$ & (0.104) \\
\hline Business and service personnel & -0.017 & $0.172^{*}$ \\
\hline & $(0.071)$ & $(0.094)$ \\
\hline Production, transport equipment & & \\
\hline & $\begin{array}{l}-0.082 \\
(0.068)\end{array}$ & $\begin{array}{c}0.170^{*} \\
(0.099)\end{array}$ \\
\hline Job through formal labour market & -0.021 & $-0.111^{* *}$ \\
\hline & $(0.046)$ & $(0.054)$ \\
\hline Self-employed or family business & $-0.114^{\star \star}$ & -0.05 \\
\hline & $(0.051)$ & $(0.061)$ \\
\hline Income (In) & $0.106^{* *}$ & $0.103^{* *}$ \\
\hline & $(0.035)$ & $(0.044)$ \\
\hline Working hours & $-0.033^{\star *}$ & $-0.039^{* *}$ \\
\hline & $(0.011)$ & $(0.013)$ \\
\hline On-the-job training & $0.213^{\star * *}$ & 0.081 \\
\hline & $(0.048)$ & $(0.058)$ \\
\hline Dangerous or toxic work & $-0.093^{*}$ & $-0.239^{* *}$ \\
\hline & $(0.056)$ & $(0.077)$ \\
\hline Regular health checks & $0.161^{\star * *}$ & $0.177^{\star \star}$ \\
\hline & $(0.049)$ & $(0.057)$ \\
\hline Defaulted on wage & -0.115 & $-0.184^{*}$ \\
\hline & $(0.086)$ & (0.095) \\
\hline _cons & $2.380^{\star * *}$ & $2.464^{\star \star *}$ \\
\hline & $(0.304)$ & $(0.393)$ \\
\hline R-squared & 0.128 & 0.166 \\
\hline F-statistic & 6.825 & 5.704 \\
\hline N. of Obs. & 621 & 386 \\
\hline
\end{tabular}

${ }^{* * *}$ significant at $1 \%$ level; ** significant at $5 \%$ level; * significant at $10 \%$ level. 